\title{
Economic Prospects of Innovative Technologies of In Vitro Cultivation of Seedlings
}

\footnotetext{
Submitted 19/01/19, 1st revision 15/02/19, 2nd revision 10/04/19, accepted 26/05/19

Morkovina S.S., ${ }^{1}$ Matveev S.M. ${ }^{2}$, Ivanova A.V. ${ }^{3}$, Sukhova V.E. ${ }^{4}$ Abstract:

Purpose: The article discusses the economic prospects of innovative technologies for planting material of forest trees. The results of the development of an organizational model of business processes of growing forest seedlings are given and the stages of reproduction technology are described, its competitive advantages are revealed.

Structure/Methodology/Approach: The use of innovative technologies in reforestation and afforestation in Russia remains insufficiently developed. Promising methods of reforestation is the use of seedlings grown by cloning.

Findings: The duration and cost for each stage of the forest seedling technology were determined. The technology of clonal micropropagation includes a combination of techniques, the choice of a donor plant and the preparation of the source material of the species.

Practical implications: It has been established that the development and introduction of technological innovations into practice requires financial support, due to the high cost of growing seedlings of woody plants. The developed organizational model of the process of clonal micropropagation can be used in organizing the production of seedlings of woody plants in forest seed breeding centers.

Originality/Value: The development of clonal breeding technologies for modern breeding and seed centers is promising, however, there are a few difficulties that impede the successful development of production and reduce the economic efficiency of reforestation activities.
}

Keywords: In vitro, forestry, innovative technologies, economic production.

JEL Code: C81, O32, Q23, Q51.

Paper Type: Research article in Special Issue dedicated to Russian Economy.

Section 8: Business and Economic Issues.

${ }^{1}$ Doctor of Science (Economics), Professor, Voronezh State University of Forestry and

Technologies named after G.F. Morozov, Voronezh, Russia, tc-sveta@mail.ru

${ }^{2}$ Doctor of Science (Biology), Professor, Voronezh State University of Forestry and

Technologies named after G.F. Morozov, Voronezh, Russia, lisovod@bk.ru

${ }^{3}$ Candidate of Science (Economics), Associate Professor, Voronezh State University of

Forestry and Technologies named after G.F.Morozov, Voronezh, anna_iv_1989@mail.ru

${ }^{4}$ Candidate of Science (Philosophy), Associate Professor, Director for Academic work,

Voronezh Branch of Admiral Makarov State University of Maritime and Inland Shipping,

Voronezh, Russia, vrngumrf@mail.ru 


\section{Introduction}

Forests are the most common ecosystems of our planet, providing habitats for more than half of known plant and animal species. Russia, which accounts for $22 \%$ of the world's forest resources, takes a special place in the conservation of the world's forest biodiversity and fulfillment of ecosystem functions

The contribution of the forest sector to national economies is one of the indicators of effective forest management. Figure 1 shows the global trend of annual GDP contribution in the forest sector. GDP per hectare of production forests has declined in Canada and the United States of America. GDP per hectare of production forests remains high in Europe over the past years. Moreover, the forest sector is particularly important in Estonia and Latvia where it accounts for more than $4 \%$ of GDP. Among all developed countries, the contribution of the forest sector to GDP is the highest one in Finland (4 percent of GDP in 2016). It is also significant in Sweden (3 percent of GDP), and in Austria and Portugal (just under 2 percent in both countries). The forest sector is less than 1 percent of their GDP in other Western European countries.

Twenty years ago, the forest complex of Russia was in the top five among developed countries, but it has dramatically slowed down its development in recent years. Since then, the production of forest products has decreased almost 3 times. Russia is significantly inferior to the countries of Europe and America in terms of annual harvesting of wood per 1 hectare. The main reason for the decline in production is both technical and technological backwardness of production, as well as systemic lagging in the volume of forest regeneration works from the volume of logging (Evlakov et al., 2014).

Figure 1. Dynamics of annual GDP of the forest sector per 1 ha of production forests, \$ (blue histogram), annual harvesting of timber in production forests, cub $\mathrm{m}$, per 1 hectare (red line)

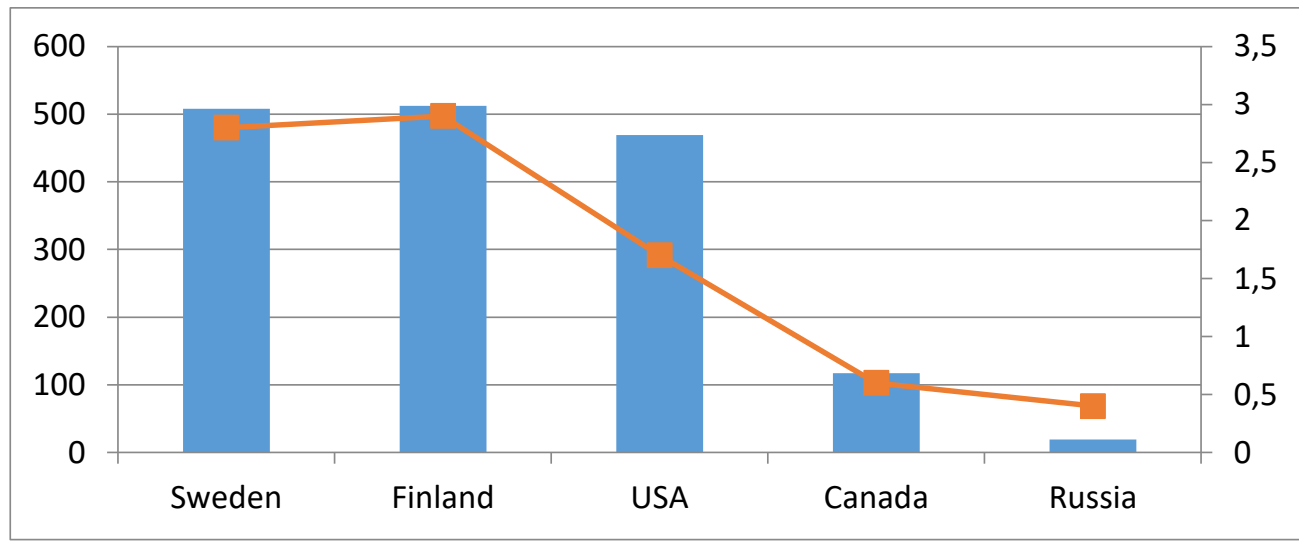


According to the Commission on Genetic Resources in Food and Agriculture (FAO), the total area of forests on our planet is steadily decreasing. Every year, 13 million hectares of forests disappear, mainly due to the redirection of land use for other purposes. This loss is somewhat compensated by new forests and forest restoration on an area of 5.7 million hectares, however, about 200 square kilometers of forests are lost on Earth every day. One of the main tasks related to the development of forestry is the fulfillment by forests of ecosystem functions and the conservation of world biodiversity, is the reproduction of forest resources.

According to the FAO of Russia, the areas in need of reforestation in the Russian Federation are 31749.9 thousand hectares, despite the fact that only 850 thousand hectares are restored annually, and the proportion of forest crops created with planting material with improved hereditary and desired properties is $4.3 \%$ (Korchagin et al., 2014).

Table 1 shows data on the required and real_volume of forest seedlings in recent years. Since 2013 the demand for forest seedlings significantly exceeds supply.

Table 1. Dynamics of forest seedlings necessity in the Russian Federation

\begin{tabular}{|l|c|c|c|c|c|c|c|}
\hline & 2011 & 2012 & 2013 & 2014 & 2015 & 2016 & 2017 \\
\hline Demand, mln pieces & 736.7 & 732.3 & 779.0 & 733.1 & 734.1 & 655.5 & 618.0 \\
\hline Supply, mln pieces & 879.8 & 831.6 & 674.0 & 721.0 & 728.1 & 594.9 & 605.0 \\
\hline $\begin{array}{l}\text { Including with closed } \\
\text { root system (CRS), mln } \\
\text { pieces }\end{array}$ & 11 & 27 & 38 & 41 & 43 & 46 & 53 \\
\hline $\begin{array}{l}\text { The imbalance of supply } \\
\text { and demand, mln pieces }\end{array}$ & 143.1 & 99.3 & -105.0 & -12.1 & -6.0 & -60.6 & -13.0 \\
\hline
\end{tabular}

Growing forest seedlings is carried out in forest nurseries, greenhouse complexes and forest breeding and seed centers. Forest nursery areas occupy about 12 thousand hectares on the territory of the Russian Federation. Currently, 574260.8 thousand seedlings are grown in forest seed breeding centers located in the Russian Federation, including 43.2 million seedlings with CRS. It should be noted that these or other mechanisms with a closed root system and micro-clonic biotechnology are used to speed up the processes of forest reproduction in Europe and America (Ivanova et al., 2018; Vasilyev et al., 2014).

Biotechnology is also used to accelerate the reproduction of forests in the forestry of the Russian Federation, but the number of growing innovative methods remains low. Depending on the tree species, the volume of forest resources varies from 12.0 to 5996.0 thousand saplings, which does not exceed $6 \%$ of the total forest resources in the country's forestry (Figure 2). 
Figure 2. Number of forest seedlings grown with CRS

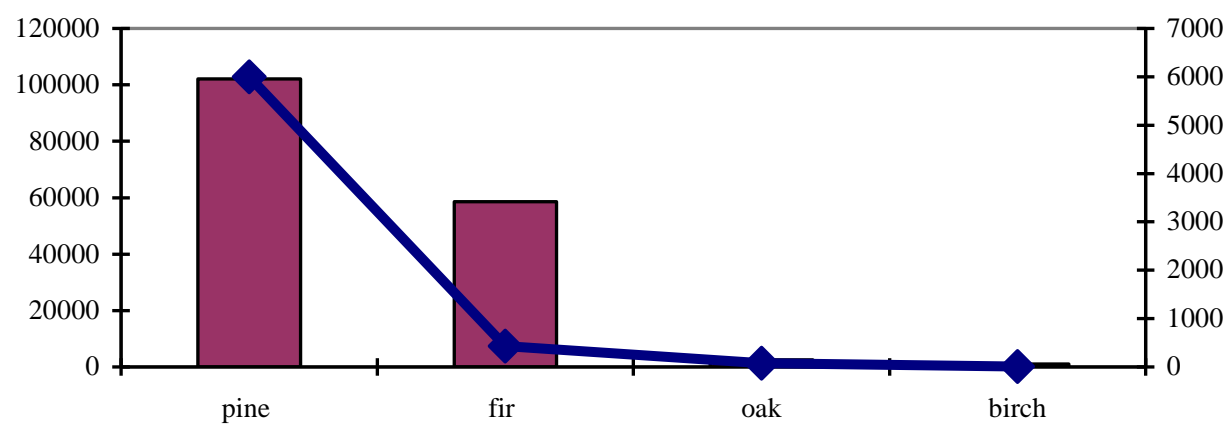

It should be noted that there is a large number of research groups in Europe and Asia which deal with the problems of intensive forest restoration based on biotechnology. Microclonal reproduction is recognized as an effective method of rapid reforestation with high quality seedlings of woody plants that do not contain phytopathogens, such as oak, birch, poplar, aspen, pine and others (Morkovina et al., 2015).

Microclonal propagation of woody plants is important primarily for growing needs for biomass and forest products (Gantait et al., 2018). The Russian Federation significantly lags behind the leading countries in the development of biotechnology: there are practically no biotechnological productions and technological solutions in the field of forestry.

In the last forty years, in vitro protocols have been developed in Europe, Asia and America for the purpose of regenerating tree species (Venkatachalam et al., 2015; Žiauka et al., 2013; Diego et al., 2010). Despite the importance of experimental research, in the case of the reproduction of forests in general, and with microclonal reproduction of woody plants, they cannot provide all the necessary information to evaluate the behavior of processes in time and space.

Moreover, this whole process can take place in changing conditions and dynamic factors of the external environment (for example, global climate change, the development scenario of which also lacks a common opinion). All this makes it necessary to develop technological solutions for growing forest seedlings using simulation.

First, such process models, based on available empirical data, can extrapolate the results of experiments on large temporal and spatial scales.

Secondly, it is possible to optimize the need for resources only with the help of process modeling. Thus, it is possible to create technologies only with the help of process modeling, both with changing natural factors, and with different modes. 


\section{Materials and Methods}

Estimated consumption for the planning and execution of specific work on the production of planting material (microplants) in vitro according to the adopted technological schemes is made in the form of calculation and process card.

In the construction and development of regulatory and technological maps, methods of working time photographs, time observers, and rationing are used. A process approach and modeling were used in the development of technological solutions for the intensive restoration of forests based on microclonal reproduction of fastgrowing hardwoods resistant to phytopathogens. The production cost of growing poplar and birch micro-clones is determined based on the direct costs of:

- Remuneration of employees directly involved in the workplace;

- Equipment maintenance (depreciation);

- Purchase of materials and fuel;

- Consumed electricity.

When developing an organizational model of business processes of growing forest seedlings, the software product Business Studio 4.0 was used.

\section{Results and Discussion}

The technology of clonal micropropagation of aspen, birch and poplar includes a combination of techniques:

- Selection of a donor plant and preparation of the source material of the species;

- Explanting the original plant tissue;

- Primary explants of poplar, aspen in vitro;

- In vitro clonal micropropagation;

- Rooting of isolated shoots;

- Adaptation and rearing of rooted microclones in greenhouse conditions.

Figure 3 presents a contextual diagram reflecting the stages of clonal micromultiplication technology. This diagram is a general description of the model and its interaction with the external environment. The use of organizational models to justify technology is reasonable (McKenney et al., 2006; Ramlal et al., 2009). The technology of clonal micropropagation of aspen, birch, and poplar can be used as a methodological support for growing seedlings of woody plants in forest seed breeding centers of the Russian Federation and greenhouse complexes.

We have constructed process and subprocesses diagrams that include descriptions of the techniques and operations, consumed and attracted material, labor and financial resources. Using the process approach, regulatory and technological maps have been constructed and economic indicators of seedling growing under conditions of 
optimal production in Table 2 have been determined. The calculations are performed on the example of poplar and birch regenerants. Monitoring of technological processes was carried out for the preparation of regulatory and technological maps, determined from the duration and costs for each stage of the technology.

Figure 3. Technological stages of forest plants micropropagation

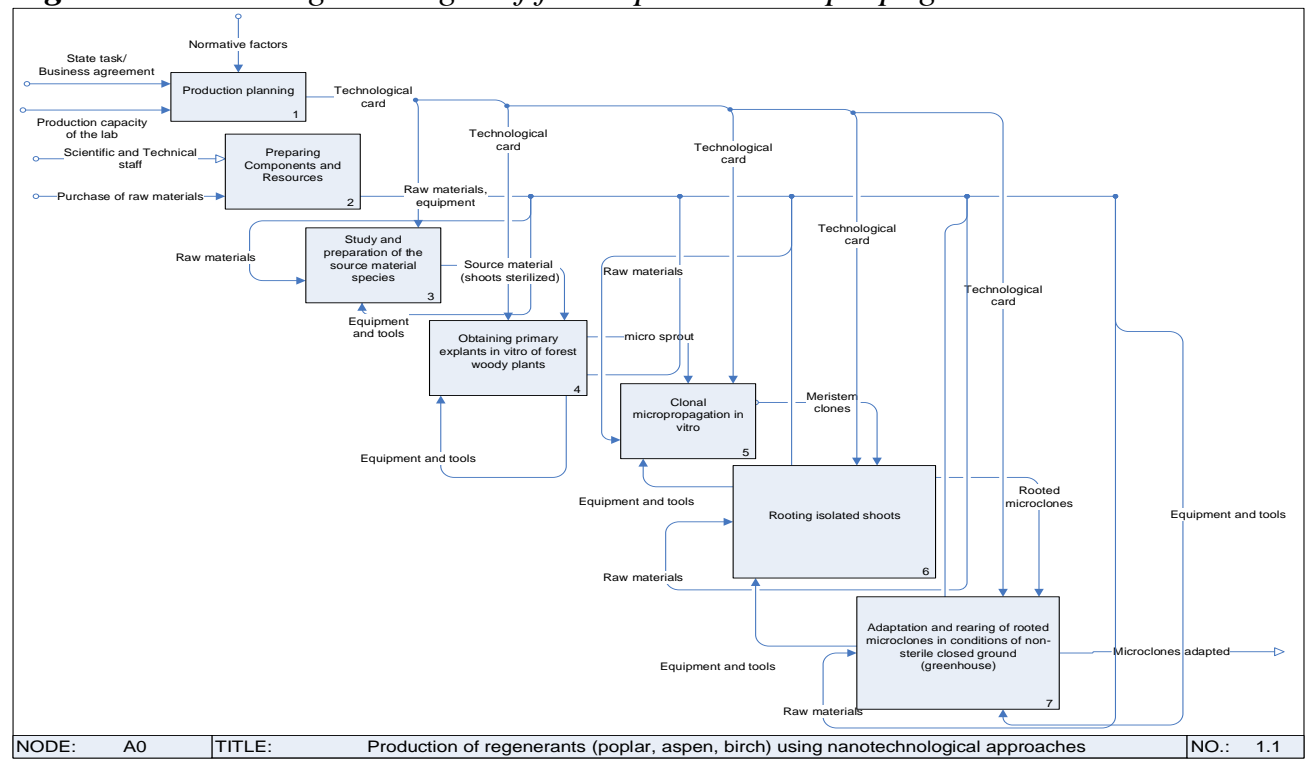

Table 2. The cost of forest seedlings, grown in vitro

\begin{tabular}{|l|c|c|}
\hline \multirow{2}{*}{ Indicator } & \multicolumn{2}{|c|}{ Value } \\
\cline { 2 - 3 } $\begin{array}{l}\text { Equipment depreciation, machine } \\
\text { maintenance, rub }\end{array}$ & 29691.9 & 30153.7 \\
\hline Wages, rub & 30899.0 & 34297.2 \\
\hline Raw material, rub & 12439.5 & 14129.0 \\
\hline Electricity, rub & 5035.3 & 5040.1 \\
\hline Fuel, rub & 286.5 & 286.5 \\
\hline Total production cost, rub & 78352.4 & 83906.6 \\
\hline $\begin{array}{l}\text { Overhead (25\% from production cost), } \\
\text { rub }\end{array}$ & 19588.1 & 20976.7 \\
\hline Total cost, rub & 97940.5 & 104883.3 \\
\hline Total output of microclones & 2250 & 2250 \\
\hline Production cost of in vitro regenerant, rub & 34.8 & 37.3 \\
\hline Overhead for poplar regenerant, rub & 8.7 & 9.3 \\
\hline Total cost of poplar regenerant, rub & 43.5 & 46.6 \\
\hline Profit 25\%, rub & 8.7 & 9.3 \\
\hline Price of one regenerant, \$. & $\mathbf{0 . 8 0}$ & $\mathbf{0 . 8 5}$ \\
\hline
\end{tabular}


It has been established that the most labor-intensive and cost-intensive stage of the technological process is the process of regenerants growing in greenhouse conditions. Production costs, including labor costs, materials, maintenance of machinery and equipment, electrical energy and fuel for one regenerant are high and it amounts to $\$ 0.53$ for poplar regenerants and $\$ 0.57$ for birch regenerants. When growing forest seedlings in greenhouse conditions, a significant part of the costs is not included in the production cost and, according to various estimates, amounts to $25 \%$ of the costs. The total cost of growing poplar microclones will be $\$ 0.67$ for poplar regenerants and $\$ 0.72$ for birch regenerants. When determining the price of one seedling, we assumed a profit rate of $25 \%$, considering what the selling price of poplar microclones will be $\$ 0.80$ for poplar regenerants and $\$ 0.85$ for birch regenerants.

According to the results of calculations, it was concluded that planting material grown and adapted in the greenhouse (innovative technology) will not be competitive, first, at a price with analogues - forest seedlings grown using traditional technology.

However, the biological characteristics of microclones grown in vitro are superior to those of similar tree species grown in open ground conditions which override the need to introduce this technology into production. The transition from laboratory to production conditions will reduce the complexity of work using specialized equipment and automated process of microclones growing.

\section{Conclusions}

The transition to innovative technology in the sectors of the national economy suggests the presence of economic effect. For forestry, in addition to economic efficiency, the role of the ecological effect, reflecting the qualitative characteristics of trees, such as growth rate, resistance to adverse effects, etc., is important. In this regard, the introduction of innovative technologies in the forest sector of Russia should take into account environmental challenges. The development of clonal propagation technologies for modern industrial complexes is promising, however, there are a number of difficulties that in some cases impede successful microclonal reproduction and reduce the economic efficiency of reforestation activities.

The developed organizational model of the process of clonal micropropagation of aspen, birch and poplar can be used as a methodological support for growing seedlings of woody plants in forest breeding and seed-growing centers and greenhouse complexes.

With the developed technology, the cost of growing poplar and birch regenerants is 0.67 and $\$ 0.72$, respectively. Cost reduction is possible due to the massive cultivation of microclones in the automation of production. 


\section{References:}

Diego, N.D., Montalbán, I.A., Moncaleán, P. 2010. In vitro regeneration of adult Pinus sylvestris L. trees. South African Journal of Botany, 76(1), 158-162.

Evlakov, P.M., Suhova, V.E. 2016, Forest investment attraction seed selection and production center: practice-oriented approach. Lesotekhnicheskii zhurnal, 1(21), 220-231.

Gantait, S., Kundu, S., Das, P.K. 2018. Acacia: An exclusive survey on in vitro propagation. Journal of the Saudi Society of Agricultural Sciences, 17(2), 163-177.

Ivanova, A.V., Kolesnichenko, E.A., Matveev. S.M., Morkovina, S.S. 2018. Management of Reforestation Processes Using Innovative Technologies. Innovation Management and Education Excellence through Vision 2020 Proceedings of the 32st International Business Information Management Association Conference (IBIMA), 1817-1824.

Korchagin, O.M., Zivonieva, I.S., Popova, Y.N., 2014. Descriptive Analysis of Introduction of Innovative Technologies in Forestry. Asian Social Science, 10(23), 20-27.

McKenney, D.W., Yemshanov, D., Fox, G., Ramlal, E. 2006. Using bioeconomic models to assess research priorities: a case study on afforestation as a carbon equestration tool. Canadian Journal of Forest Research, 36, 886-890.

Morkovina, S.S., Drapalyuk, M.V., Evlakov, P.M., Safonova, N.A. 2015 Innovational Mechanisms of Biotechnologies Support in Forest Sector for Providing Economic Security of the State. Asian Social Science, 11(20), 41-48.

Ramlal, E., Yemshanov, D., Fox, G., McKenney, D. 2009. A bioeconomic model of afforestation in Southern Ontario: integration of fiber, carbon and municipal biosolids values. Journal of Environmental Management, 90, 1833-1843.

Vasilyev, O.I. 2014, Innovacionnaja infrastruktura sistemy lesnogo hozjajstva: lesnye selekcionnosemenovodcheskie centry. Lesotekhnicheskii zhurnal, 4(16), 221-231.

Venkatachalam, P., Kalaiarasi, K., Sreeramanan, S. 2015 Influence of plant growth regulators (PGRs) and various additives on in vitro plant propagation of Bambusa arundinacea (Retz.) Wild: A recalcitrant bamboo species. Journal of Genetic Engineering and Biotechnology, 13(2), 193-200.

Žiauka, J., Kuusienè, S., Šilininkas, M. 2013. Fast growing aspens in the development of a plant micropropagation system based on plant-produced ethylene action. Biomass and Bioenergy, 53, 20-28. 